\title{
2
}

\section{DECENTRALISATION AND COVID-19}

\section{Stress-testing the Spanish territorial system}

\author{
Mikel Erkoreka, Mireia Grau Creus and Mario Kölling
}

\subsection{Introduction}

In mid-March 2020, the Spanish government triggered the constitutional mechanisms that were necessary for it to declare a state of alarm and embark on drastic measures to combat the spread of Covid-19, measures that involved curtailing fundamental rights. This was the first time the country had faced a deadly nationwide pandemic. It took the institutional and political system by surprise, deprived as it was of any experience of reacting to crises of this kind as a decentralised entity; moreover, Spain was far from placid when the virus struck, finding itself amidst turbulence blowing in from different social and political fronts.

This chapter sets out to examine how the country's governance system and territorial model responded to the stress test forced on it by the Covid-19 pandemic. The analysis covers the period from March to October 2020, which allows us to consider how institutional responses and intergovernmental relations (IGR) evolved between the domestic outbreak of the coronavirus and the start of a second declared state of alarm.

To set the scene, Spain has an area of $506,000 \mathrm{~km}^{2}$ and a population of 46.3 million, making it the second-largest country by size in the European Union (EU) and the fifth largest by population. A high proportion of the population lives in urban areas, and the country has a number of sizeable cities - the two largest are Madrid and Barcelona, which have populations of 6.2 million and 5.2 million, respectively. Spain's population density is lower than that of most other Western European countries.

The 1978 Constitution introduced a form of political organisation that saw the country shift from a highly centralised system to, according to some, a quasifederal arrangement. At present, Spain is divided into 17 autonomous communities 
(ACs) and the autonomous cities of Ceuta and Melilla. Decentralisation has been moderately successful, although for years experts have been calling for the Constitution to be revised in order to reflect the current reality of the territorial model and establish a federal framework ensuring an equilibrium between unity and diversity, shared rule and self-rule.

Spain is credited with one of the best-performing health systems in the world, having been ranked 15th in the Global Health Security Index in 2019 (Johns Hopkins Bloomberg School of Public Health 2019). Life expectancy in Spain is the highest in the EU, and social inequalities in health are less pronounced than in many other countries. However, an ageing population and the associated increase in chronic diseases pose some risks to the system's sustainability.

After the global financial crisis of 2008 and the prolonged recession that ensued, public spending on health decreased for several years before beginning to increase again recently. Since 2014 the trend has been towards an increase in expenditure per capita in all ACs. However, the differences between the ACs are important. There is in 2019, on the one hand, a group of ACs with expenditure of about EUR 1,200 per inhabitant (Andalusia, Madrid, Catalonia, and Murcia) and, on the other, a group where it is about EUR 1,700 (Basque Country, Navarre, and Asturias). In general terms, in 2019 health spending per capita in Spain was more than 15 per cent lower than the EU average (OECD and European Observatory on Health Systems and Policies 2019).

As regards the political landscape, Spain has been in crisis mode for a decade. The economic and financial crisis has led to the so-called crisis of representative institutions in which there has been a huge loss of popular confidence in aspects of the democratic system. At the same time, the secessionist conflict in Catalonia intensified in 2012, culminating in 2017 in a unilateral declaration of independence. This was followed by the application of article 155 of the Constitution, which empowered the central government to remove the Catalan government, impose direct rule, dissolve the parliament, and call for snap elections that took place on 21 December 2017. ${ }^{1}$ In parallel, the leaders of the independence movement were prosecuted and jailed.

The conflict in Catalonia has hindered reforms of the territorial model, for example, of the Senate or the territorial funding system. More widely, reform initiatives in general have not been successful, due to, among other things, party politics. From the mid-1980s to the mid-2010s, Spain's party system was dominated by a straightforward competition between the social-democratic Spanish Socialist Workers Party (PSOE) and the conservative People's Party (PP). Since 2014, however, the leftist Podemos party and the centre-right liberal Ciudadanos have entered the national arena, the moderate nationalist Catalan forces have collapsed, and a radical-right populist party, Vox, has emerged with strength. Due to the fragmentation and polarisation of the party system, 
since 2015 no party has been able to form a stable governmental majority after elections.

The fragmentation of the party system intensified after the 2019 general elections, when 22 parties obtained representatives in the Congress of Deputies, the lower house of the Spanish parliament. In January 2020, a minority left-wing coalition government consisting of the PSOE and Unidas Podemos ('United We Can') came to power. This first Spanish-wide coalition government since the Second Republic (1931-1939) had a long to-do list. After years of austerity policies, the new government wanted to increase public spending; it was also ready to start a dialogue with political parties in Catalonia on how to resolve the crisis in the region.

In contrast to the turbulent political panorama, economic growth remained solid before the outbreak of the 2020 pandemic. Nevertheless, in November 2019, the European Commission decreased its gross domestic product (GDP) growth forecast for Spain from 2.6 per cent to 1.9 per cent. Growth rates were expected to slow down even further in 2020 to 1.5 per cent, which was already worrisome given the size of the country's public debt burden.

The coronavirus's entry into Spain was confirmed on 31 January 2020, when a German tourist on the Canary Islands became the country's first case of Covid19. Community transmission had begun by mid-February; at the beginning of March, Spain recorded its first Covid-19 fatality, and by 13 March, cases had been confirmed in all the ACs, with the death toll rocketing. At the start of June, there were no reported fatalities, but afterwards the number of cases again increased. In September, health authorities were detecting greater numbers of new infections than they had witnessed in April and May.

Nevertheless, July had marked a turning point. The situation in that month was very different than in the months before it. During the first wave of infections - only serious cases were recorded; from July onwards, many of those who tested positive had but minor symptoms or were asymptomatic, a shift that pointed to the onset of a second, and more expansive wave of the pandemic. As at the end of October, health authorities had detected more than 1.2 million cases, and there were more than 36,500 confirmed deaths (Centro de Coordinación de Alertas y Emergencias Sanitarias 2020). These statistics placed Spain among the worst-affected countries in the world.

\subsection{The federal constitutional and legislative framework}

Since the 1980s, Spain developed from a unitary state with a long-standing centralist tradition into a highly decentralised state. However, the Constitution does not clearly establish a decentralised system; instead, it contains rules and procedures to be followed in order to achieve self-government. Some competences are expressly attributed to the central state (Constitution, article 149), whereas all matters not allocated to it may be assumed by the AC (Tudela and Kölling 2020). 
In 2020, the ACs had assumed most of the competences available to them, such as health, disaster management, education, and regional economic development. Nevertheless, the central state continued to maintain, as it does generally, the responsibility of coordinating state-wide policy-making.

In regard to the health-care system, it is based on the principles of universality, free access, and equity. Coverage is funded mainly by taxes, and care is provided predominantly within the public sector (Bernal-Delgado, et al. 2018).

Responses to the Covid-19 crisis were based largely on the constitutional provisions regulating one of the three types of states of exceptionality: that of the state of alarm. Of the three exceptional regimes provided for in article 116 of the Constitution and in Organic Law 4/1981 - the states of alarm, emergency, ${ }^{2}$ and siege ${ }^{3}$ - only the state of alarm expressly provides that it may be declared in the event of health crises such as epidemics and situations of serious pollution (Organic Law 4/1981, article 4(b)). However, the Constitution establishes several limits (article 116(2)): measures taken under a state of alarm must be temporary, confined to a specific area, and restricted to what is necessary to contain the emergency.

Furthermore, if the emergency is limited to a specific AC, the latter can request that the central government declare a state of alarm in its territory. The central government or the government of the affected ACs may serve, in case of a state of alarm, as the competent authority. Accordingly, the authorities have a wide margin of discretion to determine measures under a state of alarm - for example, the first state of alarm was decreed in 2010 solely to maintain control of Spanish airports following a strike by air-traffic controllers.

The Organic Law 3/86 on Special Measures in Matters of Public Health lists the conditions under which the central or AC health authorities may, within their jurisdictions, adopt public health measures in times of emergencies. According to article 3 , health authorities may, in addition to general preventative actions, take appropriate measures for the control of persons who are or have been in contact with infected persons or their immediate environment, as well as take measures necessary to prevent the risk of transmission.

\subsection{Preparedness for a national disaster: The institutional framework}

As mentioned, Spain had no experience of dealing with a disaster like Covid-19. For instance, unlike the rest of Europe, it had not been affected by either SARS (Severe Acute Respiratory Syndrome) or MERS (Middle East Respiratory Syndrome). The country has, however, been embroiled in a long-term conflict with the terrorist organisation ETA (Basque Homeland and Liberty) and, since the early 2000s, with international jihadism. The Madrid terrorist bombings of 11 March 2004 led (temporarily) to improved coordination among the National Intelligence Agency, the armed forces, and the police and security forces of the ACs. 
In 2013, the National Early Warning and Rapid Response System, or Sistema Nacional de Alerta Precoz y Respuesta Rápida (SIAPR), was created. Within this system, the Coordination Centre for Health Alerts and Emergencies - a Spanish health ministry department - assumes the functions of coordination, notification, and evaluation of epidemiological or pandemic crisis. SIARP was favourably evaluated in the Global Health Security Index 2019, although it was ranked low for its ability to prevent and react to pandemic challenges - in particular, because the only intergovernmental relations for which it provides involve meetings at the lower administrative level rather than engagement between the central government and ACs (Arteaga 2020). As it proved, the Coordination Centre for Health Alerts and Emergencies was quickly overwhelmed by the Covid-19 crisis at its outset in March 2020 and unable to collect data in a timely, orderly way.

\subsection{Rolling out measures to contain the pandemic}

In analysing the evolution of the framework of action at federal and state level, it is necessary to differentiate between four consecutive stages of pandemic response, as shown in Figure 2.1:

1. the period of the appearance and spread of the virus prior to the declaration of the first nationwide state of alarm (late January-13 March);

2. the period in which the first state of alarm was in force and was then deescalated (14 March-21 June);

3. the period of the 'new normality' (22 June-24 October); and

4. the period of the second nationwide state of alarm (25 October-9 May 2021).

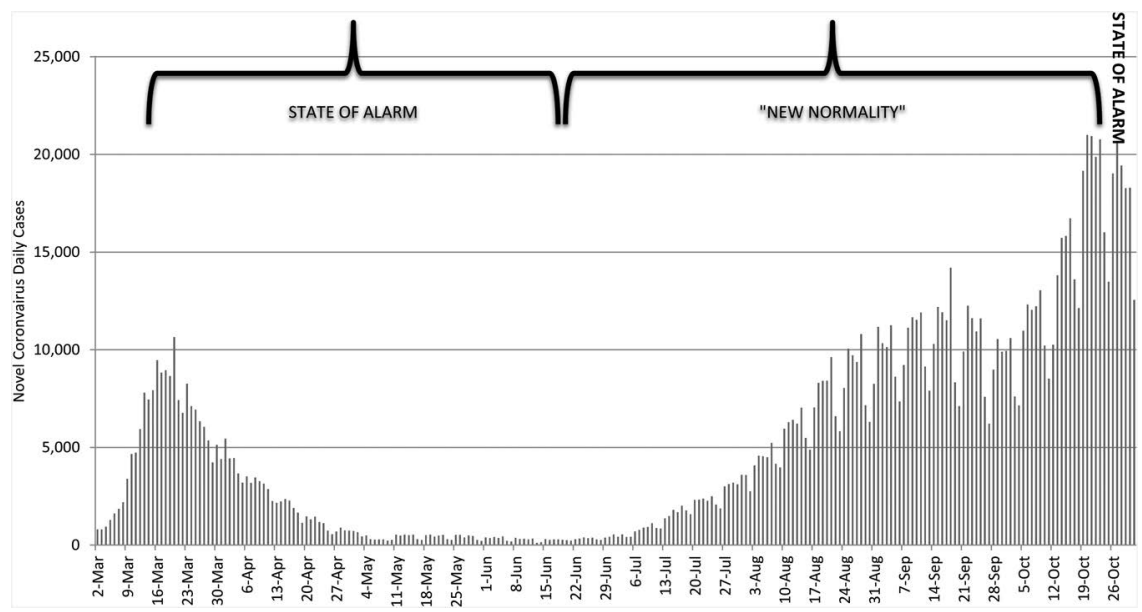

FIGURE 2.1 New Covid-19 cases in Spain per week, March-October 2020 Source: Spanish Ministry of Health (2020). 


\subsubsection{Taking the initiative}

The virus began to spread erratically and unevenly across Spain and its ACs at the end of January 2020. In this first stage, the ACs played a leading role in taking measures to contain it, albeit in an uncoordinated, under-planned fashion, with each AC applying measures of its own depending on the prevalence of the virus in its territory. The measures failed to curb the increase and spread of cases in the country as a whole.

On 9 March, by which point there were already more than 1,500 confirmed cases, the central government issued initial warnings and countrywide recommendations; on 13 March, when the figure had exceeded 7,500, Prime Minister Sánchez (in office since June 2018) announced a nationwide state of alarm. In a comparative perspective, Spain was a notable laggard in raising the level of response, given that other countries had done so when they reached 1,000 confirmed cases (Timoner 2020).

\subsubsection{Federal action}

Spain's state of alarm was declared under Royal Decree 463/2020, which came into force on 14 March 2020 and conferred full responsibility on the national government to manage and implement measures for addressing the Covid-19 crisis. Such measures included placing the country under a lockdown compelling people to stay at home, as well as ensuring the supply of goods and services needed for health, food, and power. On 29 March, under Real Decreto-ley 10/2020, all non-essential workers were ordered to remain at home for 14 days. In addition, the central government adopted legislative measures addressing health matters and the economy at large, with the focus on small and medium-sized enterprises, the self-employed, persons affected by the lockdown, and the tourism industry.

The declaration of the state of alarm allowed the central government to suspend, and then assume, the powers of the ACs for a period of 15 days. The Prime Minister delegated authority to the ministers of health, defence, internal affairs, and transport, mobility, and urban affairs in their respective areas of responsibility, with any residual responsibility being assumed by the Minister of Health.

With the creation of the mando unico (single command), the Minister of Health formally assumed the responsibility for decision-making and coordination of health policy decisions in the 17 ACs. The ministry was supported by the research organisation, the Institute of Health Carlos III (ISCIII), which managed the country's epidemiological surveillance in coordination and collaboration with the ACs.

Considering that health competences have been in the hands of the ACs for almost two decades, the central government's position to undertake coordination was weak. During the first weeks, the Ministry of Health could not obtain and provide operational data, let alone coordinate joint actions with the ACs in, for example, the procurement of protective clothing and masks (Kölling 2020). 
The economic and social costs of the lockdown were very high. To address this situation, the central government approved the mobilisation of nearly EUR 200 billion, an amount to account for about 20 per cent of the Spanish GDP (see section 2.4.6 for a fuller discussion). The pandemic also caused serious interference with the Congress of Deputies, as the latter's parliamentary activity was reduced to a minimum - basically, to voting several times to extend the state of alarm. This reinforced the traditionally weak position of the Spanish parliament vis-à-vis the executive, all the more so given that the proclamation of the state of alarm further strengthened the executive. Nevertheless, the Congress retained important leverage by virtue of its role in approving the state of alarm and its extensions (Kölling 2020).

At the request of the government, the Congress authorised six extensions of the state of alarm, which ended on 21 June 2020 (see Table 2.1). The first extension, from 25 March to 11 April, was passed with the support of 269 of the 350 members of the Congress; only the members of Vox abstained. However, in subsequent votes the level of criticism increased, with the PP, which abstained in the votes for the third and fourth extensions, voting against the fifth and sixth extensions. In addition, the pro-Catalan independence parties, the left-wing Esquerra Republicana de Catalunya (ERC) and conservative Junts per Catalunya (JxC), voted against the fourth extension after unsuccessfully trying to get the central government to agree to convene a 'negotiation table' with the Catalan government in exchange for a vote for another extension.

The increasing polarisation in Parliament was also reflected in major demonstrations against the Spanish government in April and May 2020. These were organised mainly by Vox and partly by the PP; however, neither party was able to benefit significantly from the crisis.

On 28 April 2020, the Spanish government presented a four-phase 'Plan for the transition to a new normality'. The first phase - entailing reopening small shops and allowing café terraces to operate at 50 per cent capacity and places of worship, at one-third - came into force in some provinces on 4 May. The restrictions were thus gradually lifted by 21 June. Although the ACs did not participate in the declaration of the state of alarm, the plan to move from the state of alarm

TABLE 2.1 Spain: Congressional voting on extensions of the state of alarm

\begin{tabular}{llcl}
\hline Extensions and dates & Votes in favour & Votes against & Abstentions \\
\hline $1.25 / 03 / 2020$ & 321 & 0 & 28 \\
$2.09 / 04 / 2020$ & 270 & 54 & 25 \\
$3.22 / 04 / 2020$ & 269 & 60 & 16 \\
$4.06 / 05 / 2020$ & 178 & 75 & 97 \\
$5.20 / 05 / 2020$ & 177 & 162 & 11 \\
$6.03 / 06 / 2020$ & 177 & 155 & 18 \\
\hline
\end{tabular}

Source: Congress of Deputies (2020). 
to the 'new normality' in late June was developed in close collaboration between the central government and the governments of the ACs (Marcos 2020a).

In May, the central government announced new legal mechanisms that would facilitate the implementation of measures in 'co-governance' with the ACs without having to impose another state of alarm, albeit that at the time of this writing in October, the government had not submitted any legislative proposals to Parliament. During the 'new normality', it thus decided to coordinate decisions with ACs and clarify the ways in which they could adopt the state of alarm in their territories. For example, after an emergency meeting with health officials from the ACs, the government on 17 August announced new social-distancing measures across Spain, but it was in the hands of the ACs to implement them. Similarly, until mid-September, central government efforts were directed largely towards engaging with ACs to coordinate minimum standards for reopening schools.

However, some of the measures by the autonomous and local administrations were annulled in the courts, especially those restricting fundamental rights (mobility and social gatherings, for example), as it was ruled that they could be valid only in a constitutionally provided state of alarm. From August to October 2020, the number of new infections increased sharply, marking the second wave of the pandemic, and during this period, the government reached agreement with most of the ACs on thresholds for local lockdowns. The Community of Madrid, one of the ACs with the highest rates of infection early in the second wave, imposed local lockdowns in terms of these criteria, but the Madrid High Court ruled that the central government could not limit fundamental rights without resorting to a state of alarm. As a consequence, the central government imposed a selective state of alarm of 15 days in parts of the AC Madrid - this was a 'surgical' intervention that restricted entry and exit only in the concerned municipalities.

By mid-October, the second-wave pattern of spiked rates of infection had spread throughout the country. Faced with this situation, 11 ACs - including Catalonia and the Basque Country - asked that the central government declare a new general state of alarm to avert the need for court approval of their measures and thereby improve their speed of response and ability to take further action, such as imposing nightlife curfews and additional mobility restrictions.

On 25 October 2020, the central government declared a second nationwide state of alarm in Spain, doing so with the approval of the Congress (194 votes in favour, 53 against, and 99 abstentions), and, controversially, ordering it until 9 May 2021. The measures attendant on the declaration were set out in Royal Decree 926/2020 of the same date and included perimetral lockdowns, restrictions on social and religious gatherings, and a mandatory nationwide curfew between 23:00 and 6:00. In contrast to the first state of alarm in March, the second was implemented in a decentralised manner and managed primarily by AC governments. Measures taken under it were less severe than those under the first, as no lockdown was involved. 


\subsubsection{State action}

Before the declaration of the state of alarm, the ACs played a leading role in adopting preventative measures. In the most affected ACs, measures were decreed that closed educational centres (for example in Madrid and the Basque Country), placed restrictions on social gatherings, and introduced the first perimetral lockdowns (in La Rioja and Catalonia). On 13 March 2020, merely a few hours before the declaration of the state of alarm, the Basque government decreed a state of health emergency that enabled it to take drastic measures at the subnational level. The least affected ACs, by contrast, delayed taking measures to contain the pandemic and, when they did, imposed relatively lax restrictions.

The situation changed dramatically when the first state of alarm came into effect on 14 March. Finding themselves under the sole command of the central government, the autonomous administrations lost their decision-making capacity albeit that they remained responsible for the management of centrally issued instructions. In other words, this intervention in self-government did not bring the activities of autonomous administrations to a halt at either the parliamentary or executive level but instead placed them at the service of the central government.

Working as they did within the limits established by the central government, the autonomous governments still had a certain margin of discretion in planning and implementing their public policies. This led to, among other things, competition between ACs in acquiring medical resources on the international market, an uneven ratio of detection tests per inhabitant and territory, heterogeneity in the statistical data provided by ACs, differences among the ACs in models of cooperation between the public and private health-care sector, and obstacles to transferring patients and resources between ACs.

In addition to the improvement of the health indicators, the transition plan to the 'new normality' referred above was driven largely by pressure from the AC governments in the face of wishes by Congress to extend the state of alarm. The plan, agreed with the ACs, involved a gradual de-escalation in four phases. The transition from one phase to the next was decided by the central government on the basis of public health indicators such as an AC's number of cases and the capacity of its health-care system. In this fashion, restrictions were lifted phase by phase, territory by territory.

Having met the requirements, Galicia was, on 15 June 2020, the first AC to obtain central government authorisation to move to the 'new normality'. On 19 June, the Basque Country and Cantabria also made this transition, and free movement between these neighbouring ACs was re-established. On 21 June, after 98 days, the state of alarm ended throughout the country. In the new normality, free movement between ACs was restored.

During the transition to the new normality, the ACs gradually recovered the competences and functions that had been centralised under the single command of the central government, giving way to a scenario of co-governance of the 
pandemic between the central government institutions and the ACs. After the end of the state of alarm, the AC executives exercised their powers in managing their health-care systems, in organising Covid-19 tracking mechanisms, in developing and implementing containment measures, and in applying policies on social protection and economic reactivation. For example, ACs could decide on the use of masks, restrictions on gatherings, and certain social distancing requirements. They also developed their individual procedures for managing the start of the academic year and, in cases, imposed restrictions on mobility or selective confinements. Although there were differences among them, especially with respect to efficiency and periods of implementation, the ACs all applied similar measures and restrictions.

The second countrywide state of alarm, decreed at the end of October 2020, provided the ACs with the legal instruments to enforce more severe measures in fighting the pandemic. Furthermore, the ACs preserved the power to approve and implement measures at the regional level within the general framework set by the state of alarm. After the declaration of the second state of alarm, the ACs introduced new restrictions on mobility - including perimetral lockdowns - and social life, for example by limiting social gatherings to six people or closing bars and restaurants.

\subsubsection{Local government action}

Local governments in general kept a low political profile. The pandemic did not significantly alter the framework of either their functional or administrative competences, and as a result, they continued to take responsibility for providing basic everyday services and goods.

Given that local governments do not have relevant competences in health matters, their role in containing the pandemic focused on implementing and enforcing restrictive and preventative measures - notably, municipal police forces were central in this undertaking - and in regulating economic activity within the scope of their competences, for example in matters related to the customer capacity and opening hours of bars and restaurants.

Similarly, depending on the needs and characteristics of each municipality, local governments adopted and funded social measures to help especially vulnerable groups and facilitate social cohesion, for instance through assistance in paying for housing or support to poor families. They also promoted plans and policies to aid economic recovery at the local level, for example through local tax incentives and reductions or by subsidising bonds to stimulate local commerce. Finally, it is worth noting the work of local governments in supporting cultural activity and cultural agents, a sector that was severely affected by the lockdown restrictions.

Local governments, mainly from the de-escalation onwards, had to adapt to the decisions of the respective AC executives. Nonetheless, with the exception of some isolated episodes, relations between local and autonomous administrations 
were generally collaborative. During the pandemic in 2020, no additional or extraordinary mechanisms of horizontal municipal cooperation were developed that exceeded the autonomous sphere; one way or another, organised local government did not play any significant role in this regard.

\subsubsection{Intergovernmental relations}

In the absence of any constitutional provision of shared rule involving the ACs, Spanish intergovernmental relations (IGR) were developed at the initiative of the central government authorities. IGR was envisaged initially in terms of inter-administrative interaction (and was contained in legislation on administrative cooperation) and it developed a strong administrative profile and functioning. Actually, most of the intergovernmental political interaction took place within parliamentary and intraparty arenas. In 2004, the central government established an intergovernmental forum of premiers, the Premiers' Conference (Conferencia de Presidentes), in order to promote an IGR institution that potentially could absorb some of the intergovernmental interaction usually debated in other arenas.

Spain's IGR system has at least six characteristics: hierarchical structure and functioning; a strong bilateral approach (central government and each individual AC); a lack of horizontal interaction; a deeply sectoral approach; a focus on administrative implementation; and large diversity (Arbós et al. 2009; PérezMedina 2020). Over the past decades, two mechanisms have fostered IGR: intergovernmental sectoral and multilateral forums, which are meant to bring the central government and AC ministries together to discuss and agree on policy issues, and the compacts (convenios), that is, administrative mechanisms for financing the implementation of central government policies in the ACs.

Intergovernmental sectoral forums accord central government authorities a commanding role (for instance, they set the agenda and call meetings) and, in some cases of fundamental importance, such as the forum on financing ACs, a casting vote that overrules the others. As for convenios, they are always welcome in that they provide ACs with external financing, but they reveal the influence of central government spending-power in policy areas that do not usually receive media attention. These features explain, at least in part, the very limited impact that Spain's IGR system has made in building solid political and institutional trust. Shared rule has never developed in its strict sense of involving subnational governments within nationwide decision-making processes.

In a decentralised country like Spain, where implementation powers in health matters fall exclusively under the ACs, it was clearly impossible to manage the Covid-19 crisis without intergovernmental cooperation (León 2020). However, as Capano (2020) said in remarks on Italy's management of the pandemic, 'If you are not prepared for the (un)expected, you can be only what you already are'. This meant that the first response was a hierarchical one that centralised all powers in a single decision-making unit by declaring the state of alarm. The ACs 
were left on the sidelines because, leaving political considerations aside, there are no legal or institutional provisions for them to play any role at all.

The IGR system came into play right after the declaration of the state of alarm and the publication in the Official Gazette of all measures that were adopted, when the Prime Minister called for a meeting with the AC premiers. As said, meetings of the Prime Minister and AC premiers were institutionalised in 2004, but prior to Covid-19, only six of these had been held, with the meetings rarely attended by all of the AC leaders - facts which reflect the weakness of Spain's federal culture and the problems of trust that have beset IGR for many years.

In a videoconference on 15 March 2020, two days after the declaration of alarm, the Prime Minister informed the AC premiers (17 out of 17 ACs) of the measures and asked them to commit to 'unity of action' and loyalty. An institutional manifesto confirming their commitment was released after the meeting, a benchmark in the history of this high-profile IGR mechanism. All the premiers signed it except the Catalan leader, who voiced his disagreement with the unitary command structure and what he regarded as an encroachment on subnational powers (Marcos 2020b). Although the premier of the Basque Country signed the manifesto, he too expressed strong opposition to what he saw as Spain's hierarchical and centralised approach to the crisis, declaring that 'cooperation and collaboration do not mean [acceptance of or entitlement to] imposition' (Vega and Segura 2020).

As the extensions of the state of alarm were approved one after another by the Congress, the perception that the central government's idea of cooperation was entirely top-down in orientation started to spread, in the process sparking criticism by other premiers. Given that these criticisms arose across the political spectrum and that the central government - a minority coalition - was in need of support in parliament on issues other than Covid-19, the federal-level approach to cooperation was reappraised, with the central government opening the door to some degree of participation by ACs in decision-making on the pandemic.

The wording used to describe this new approach was itself a novelty in the Spanish context. In view of the hierarchical connotations that the phrase 'intergovernmental cooperation' had acquired over the decades, the new word 'co-governance' - was chosen to stress the sense of an equalising or levelling of the status of the participants. In early May, the Spanish Ministry of Health issued a ministerial order (Order SND/387/2020 of 3 May 2020) aimed at regulating the role of the ACs in decision-making on the de-escalation phase. Although for some it was far too much, and for others far too little, the point is that it was acknowledged that the lack of institutional instruments for enabling the ACs to participate in state-wide decision-making processes was a problem linked to an unfit decentralised setting and not just to an 'incomplete' institutional setting, as it used to be defined.

In any case, and in spite of all the ups and downs, during the 98 days of the state of alarm, the Prime Minister and AC premiers' meetings stood out as the main forum for coordination, consultation, and reaching agreement on 
managing the pandemic. Virtually inoperative until the onset of Covid-19, this forum met on 16 occasions (15 of them online) while the state of alarm was in effect. In addition, the Inter-Territorial Council for the Health System had a prominent role. Throughout the state of alarm, it met online twice a week to exchange information and reach agreement on, for example, common standards for tests for Covid-19, closing bars, restricting smoking in public spaces, and measures in residences for the elderly.

Other lower-profile intergovernmental mechanisms also saw a revival - more than a hundred sectoral meetings were held between March and September 2020, whereas in the whole of 2019 there had been less than 50 (Marcos 2020a). Nevertheless, due to their entrenched sectoral perspectives and traditionally compartmentalised vision of public administration, these mechanisms did not contribute to providing the breadth of perspective the pandemic response required.

As regards the views of the actors on the functioning of the IGR mechanisms, most of the AC premiers stressed the usefulness of the Premiers' Conference despite its purely informative nature and their passive, subordinate role in pandemic management. The regularity of the meetings and the need for a problemsolving approach probably had its benefits, one of which seems to have been to re-humanise political adversaries after years of polarisation. In a television interview with the premier of Castilla La Mancha, a PSOE leader, the presenter asked him to rate the behaviour of the Catalan premier at these meetings on a scale of 'bad, very bad, worse', a question intended to elicit the antagonism the PSOE customarily has towards leaders of the Catalan government. To the surprise of the TV presenter (and no doubt the audience), he replied that the atmosphere of the meetings was actually always constructive and that many of the Catalan premier's proposals were sensible (Costas 2020).

Even allowing that this is a single anecdote without empirical data to support it, what should not be underestimated, in a context as polarised as Spain's, is the potential importance of high-profile IGR mechanisms as a means to pave the road towards de-polarisation by bringing tough adversarial politics into a space of fair play. In this regard, relationships between ACs traditionally have been poor; however, during the pandemic no additional or extraordinary instruments of horizontal cooperation among them were established. Horizontal cooperation was limited mainly to bilateral agreements between neighbouring ACs.

\subsubsection{Intergovernmental fiscal relations}

The system of financing the ACs in Spain has an asymmetrical character and is regulated under two differentiated regimes: the so-called common regime and the foral regime. The common regime is applied uniformly to all the ACs on the Spanish peninsula, ${ }^{4}$ except for the Basque Autonomous Community and Navarre, which are ruled under the foral regime. Based on their historical and political circumstances, the Basque Country and Navarre preserve a singular and privative foral system of financing and self-government, which provides 
them with broad fiscal and financial power in contrast with the common regimen ACs. Questions related to the system of financing the ACs occupy a large part of the debates on the territorial organisation of power in Spain. With regard to social security, its economic management falls under the exclusive powers of the central government, which finances the pension system and unemployment benefits, among other things.

Following the declaration of a state of alarm, the central government played a prominent role in initiating measures on social protection, economic recovery, and employment. The range of measures was extensive and includes instituting the mechanism, Temporary Employment Regulation Dossiers (Expedientes de Regulación Temporal de Empleo); the creation of a minimum living wage (safety-net income of between EUR 462 and 1,015 for the neediest of families); the mobilisation of more than EUR 150 billion in public guarantees to ensure the liquidity and solvency of the business sector; and various plans for reactivating consumption (De la Fuente 2021; KPMG 2020).

Pending the arrival of European funds and fiscal reforms that might be implemented in the 2021 budgets, these measures were funded mainly through the deficit and public debt. The Spanish central bank, Banco de España, predicted that the deficit would be above 10 per cent of GDP and that public debt would rise by more than 20 points to greater than 115 per cent of GDP in 2020 (Banco de España 2020). The ACs and local governments also formed their own plans of action to confront the health crisis, strengthen the health and social protection systems, and apply measures to support the revival of economic activity and consumption. The tax authorities of the Basque Country and Navarre, like those of the central government, also used fiscal policy to introduce flexibility into tax obligations and establish fiscal incentives to boost economic recovery.

The budgetary policies of the public administrations were conditioned by the Budgetary Stability Law, which was passed in 2012 in the context of the European rescue in Spain and sets strict targets for deficit, public debt, and expenditure. The deficit targets set for 2020 were 1.8 per cent for the public administration as a whole ( 0.5 per cent, the central administration; 0.2 per cent, the ACs; 0 per cent, local governments; and 1.1 per cent, social security). However, in March 2020 the EU activated the 'general escape clause', which allows member states facing severe economic shock not to meet the deficit and debt objectives required by the Stability and Growth Pact. ${ }^{5}$

Due to the ACs' limited financial autonomy, the central government had to provide financial assistance to them through advances on accounts, down payments from the liquidated 2018 fiscal year, and other extraordinary funds and resources. These transfers made it possible to reduce the margin of deviation in the deficit and debt targets of the ACs of the common regime. In summer, the Basque Country and Navarre, whose regime of financing is independent of the pattern of flows described above and is ruled by the principle of unilateral risk, bilaterally negotiated the adjustment of their deficit (which increased to 2.6 per cent) and debt targets for 2020 with the central government. Later, at 
the end of September 2020, the government suspended the application of the tax rules in 2020 and 2021 for all public administrations (La Moncloa 2020a). This decision authorised public administrations to relax their budgetary policies, allowing them to increase public spending. However, the central government urged the common regime ACs to limit their deficit in 2021 to 2.2 per cent; of this, the centre would assume 1.1 per cent through an extraordinary transfer of funds.

Aside from the regular system of financing, the central government approved a non-repayable fund of EUR 16 billion so that ACs could confront the impact of the pandemic (Ministry of Finance 2020). The Covid-19 Fund, made up of four sections of unconditional transfers, created tensions among the governments of ACs due to the criteria for revenue-sharing established by the central government. The distribution to ACs of the first and third sections (EUR 9 billion in total) was based on health variables. The second section, of EUR 2 billion and associated with education, was shared out according to the youth population ratios of each AC. The fourth section of the fund, to which EUR 5 billion was assigned and which excludes the Basque Country and Navarre, was aimed at compensating for the drop in tax revenues.

With the precedent of the Covid-19 Fund on the table, the sharing of EU recovery funds led to a new debate among ACs and the central government about determining the distribution criteria. Spain was to receive close to EUR 140 billion from the EUR 750 billion Next Generation EU recovery plan. On 7 October 2020, the central government presented the Recovery, Transformation and Resilience of [the] Spanish Economy Plan to guide the deployment of EUR 72 billion from EU recovery funds between 2021 and 2023 (La Moncloa 2020b). The plan is structured around four priority areas: the ecological transition, digital transformation, gender equality, and social and territorial cohesion. It does not, however, determine the territorial distribution of funds.

\subsection{Findings and policy implications}

The Covid-19 pandemic was an unprecedented challenge and severely tested both the Spanish territorial model and the national health system. The delayed reaction by the central and AC governments, poor coordination among governments, and the variance in measures and test frequency may help to explain the strong impact Covid-19 had on the country. However, many other endogenous and exogenous factors were crucial in their effect on crisis management, among them a tendency towards physical proximity and greetings, or the urban environment - Spain has one of the largest urban population concentrations in West Europe.

In such a context, the Spanish government opted for an initial response based on a centralised control, one that rapidly unveiled the institutional weaknesses of the IGR system. The political and institutional management of the first wave of infections alerted the central authorities to the logistical as well as legitimacy problems of exercising sole, unitary command; as a result, there was a switch-over to integrating the ACs in decision-making processes. Thus, managing the crisis 
brought into relief the tension between, on the one hand, the constitutionally determined framework legislation of the central government and, on the other, the reality of a country consisting of heterogeneous regional health systems. Due to a combination of party politics, territorial cleavages and long-standing institutional deficits, such as poor coordination among governments and an unclear division of competences, decisions were taken very late and slowly. However, the crisis may have been a turning point in regard to these deficits in Spain's territorial model.

In relation to funding the pandemic, as happened in earlier crises, exposed the cracks in the system for financing the ACs of the common regime and underscored their dependence on central government transfers when there is a budgetary emergency. In analogous terms, the principles of fiscal coresponsibility and unilateral risk continued to guide the framework of bilateral fiscal and financial relations between the foral ACs and the central government, once again revealing the deep differences that exist in the asymmetrical Spanish funding model.

In debates about Spain's management of the pandemic, there were calls for reform of the national health system and the strengthening of the Ministry of Health. According to these demands, the Ministry should improve its constitutionally determined coordination function and ensure national standards in health-care delivery. However, this debate should also be seen in the context of balancing institutional trust and the demand for institutionalised co-governance between the ACs and the central government, and the demand of preserving the self-government margin of the ACs, as well as the future role of the EU in crisis management. A future European Health Union may improve preparedness and resilience for cross-border health threats, but it would also affect the territorial distribution of responsibilities at the national level.

As a general conclusion, the Covid-19 crisis has made evident the structural deficits in the institutional design framing decentralisation in Spain and has changed the central government's perception on IGR. For long, the system had been analysed in terms of its assumed progressive adaptation towards federalism, as if institutions could evolve on their own. The Covid-19 crisis, by unveiling the weakness of shared rule, has brought about the questioning of traditional IGR approaches. The promotion of shared rule, at least in health matters, seems to be the most relevant institutional output. Time will tell whether this new institutional output would generate new policy dynamics and would expand to other policy areas and institutions or would stay encapsulated within the management of the pandemics.

\section{Notes}

1 Article 155 allows the central government to take measures in exceptional cases to restore constitutional order or prevent major harm to Spain's interests. In 2017 the Senate granted the government these powers to enable it to impose direct rule on Catalonia. The interpretation and application of article 155 have been widely debated. 
2 A state of emergency may be declared by the government when 'the free exercise of the citizens' rights and freedoms, the normal operation of the democratic institutions, that of the public services that are essential to the community, or any other aspect of law and order, are so seriously altered that the use of ordinary authorities is insufficient to establish it and maintain it' (Organic Law 4/1981, article 13).

3 A state of siege may be declared by the Government 'when an uprising or act of force occurs against the sovereignty or independence of Spain, its territorial integrity or the constitutional system that cannot be solved by other means' (Organic Law 4/1981, article 32).

4 The Canary Islands and the two North African enclaves of Ceuta and Melilla have a special tax regime.

5 In this volume, see Chapter 6 on the European Union.

\section{References}

Arbós, X. et al. 2009. Las Relaciones Intergubernamentales en el Estado Autonómico. La Posición de los Actores. Barcelona: Institut d'Estudis Autonòmics.

Arteaga, F. 2020. 'La Gestión de Pandemias Como el COVID-19 en España: ¿Enfoque de Salud o de Seguridad?', RIE, 2020-42.

Banco de España. 2020. 'Macroeconomic Projections Report', https://www.bde.es/bde/en/ secciones/prensa/notas/Briefing_notes/ (accessed on 19 October 2020).

Bernal-Delgado, E. (et al.). 2018. 'Spain Health System Review', Health Systems in Transition Profile, 20(2): 1-179.

Capano, G. 2020. 'Policy Design and State Capacity in the COVID-19 Emergency in Italy: IfYou Are Not Prepared for the (Un)Expected,You Can Be Only What You Already Are', Policy and Society, 39(3): 326-44.

Centro de Coordinación de Alertas y Emergencias Sanitarias. 2020. 'Enfermedad por el Coronavirus (COVID-19)', https://www.mscbs.gob.es/en/profesionales/saludPublica/ ccayes/alertasActual/nCov-China/documentos/Actualizacion_177_COVID-19.pdf (accessed on 19 October 2020).

Congress of Deputies, Spain. 2020. 'Congressional Voting on Extensions of the State of Alarm', www.congreso.es (accessed on 12 March 2021).

Costas, N. 2020. 'Zasca de García Page a Cristina Pardo tras incitarle a cargar contra Quim Torra de forma sibilina', El Confidencial, 23 March.

De la Fuente, Angel. 2021. 'The Economic Consequences of Covid in Spain and How to Deal with Them', Applied Economic Analysis, 29(85): 90-104.

Johns Hopkins Bloomberg School of Public Health. 2019. Global Health Security Index: Building Collective Action and Accountability. Washington DC: Nuclear Threat Initiative.

Kölling, M. 2020. 'Federalism and the COVID-19 Crisis: A Perspective from Spain', Forum of Federations Working Paper.

KPMG. 2020. 'Spain: Tax Developments in Response to Covid-19', https://home.kpmg/ $\mathrm{xx} / \mathrm{en} /$ home/insights/2020/04/spain-tax-developments-in-response-to-covid-19.html (accessed on 19 October 2020).

La Moncloa. 2020a. 'El Gobierno suspende la aplicación de las reglas fiscales en 2020 y 2021', 30 September, https://www.lamoncloa.gob.es/serviciosdeprensa/notasprensa/hacienda/ Paginas/2020/300920-reglas_fiscales.aspx (accessed on 19 October 2020).

La Moncloa. 2020b. 'Pedro Sánchez Presents Recovery Plan to Guide Implementation of 72 Billion Euros from European Funds to 2023', 7 October, https://www.lamoncloa. gob.es/lang/en/presidente/news/Paginas/2020/20201007recovery-plan.aspx (accessed on 19 October 2020). 


\section{Mikel Erkoreka et al.}

León, S. 2020. 'De Gestión Centralizada a Gestión Autonómica de la Pandemia: Desafíos y Oportunidades', EsadeEcPol Insight \#14.

Marcos, J. 2020a. 'Todos los Presidentes Autonómicos Cierran Filas con el Gobierno Pese a las Críticas de Torra', El País, 15 March.

Marcos, J. 2020b. 'La Crisis del Coronavirus Reactiva los Engranajes del Estado Autonómico', El País, 2 August.

Ministry of Finance. 2020. 'Fondo COVID', https://www.hacienda.gob.es/en-GB/CDI/ Paginas/SistemasFinanciacionDeuda/InformacionCCAAs/Fondo_COVID.aspx (accessed on 8 November 2020).

OECD and European Observatory on Health Systems and Policies. 2019. Spain: Country Health Profile 2019, State of Health in the EU. Paris: OECD Publishing.

Pérez-Medina, J. M. 2020. 'Dinámica de las Conferencias Sectoriales. Entre la Intergubernamentalidad y la Cooperación Administrativa', Revista d'Estudis Autònòmics $i$ Federal - Journal of Self-Government, 31: 17-64.

Spanish Ministry of Health. 2020. 'Covid-19', https://cnecovid.isciii.es/covid19/\#ccaa (accessed on 8 November 2020).

Timoner, A. 2020. 'Policy Responsiveness to Coronavirus: An Autopsy', Agenda Pública - El País, 8 June.

Tudela, J. and Kölling, M. 2020. ‘The Kingdom of Spain', in A. Griffiths, R. Chattopadhyay, J. Light and C. Stieren (eds.), Handbook of Federal Countries. London: Palgrave - Forum of Federations.

Vega, N. and Segura, F. 2020. 'El Lehendakari critica que el Estado asuma el mando, pero acatará el Decreto', El Diario Vasco, 15 March. 